\title{
Bullying and its Effective Factors in Adolescents Aged Between 10 and 18 Years Old: Evidence From a Southeastern Region in Iran, 2020
}

Samera Radmerikhi

Health Services Management Research Center, Institute for Futures Studies in Health, Kerman University of Medical Sciences, Kerman, Iran

Vahid Yazdi Feyzabadi

Faculty of Management and Medical Information Sciences, Kerman University of Medical Sciences, Kerman, Iran.

Milad Ahmadi

Modeling in Health Research Center, Institute for Futures Studies in Health, Kerman University of Medical Sciences, Kerman, Iran

Seyyid Mohammad Keyhan Sajadi ( $\sim$ k.sajadi@kmu.ac.ir)

Social Determinants of Health Research Center, Institute for Futures Studies in Health, Kerman University of Medical Sciences, Kerman, Iran

\section{Research Article}

Keywords: Bullying, Adolescents, School, Victim, Iran

Posted Date: August 3rd, 2021

DOI: https://doi.org/10.21203/rs.3.rs-762979/v1

License: () (1) This work is licensed under a Creative Commons Attribution 4.0 International License. Read Full License 


\section{Abstract}

Background \& Objective: Bullying behavior in adolescence as a global and a public health problem is of great interest in adolescence due to mental illness, violence, and tobacco addiction in adulthood. The present study aims to investigate the prevalence of both bullying and victim behaviors at all educational levels in Kerman.

Methodology: This is a survey study, in which the study population are all students at three educational levels in Kerman. Multi-stage sampling method is used. To investigate the prevalence of bullying behavior, the Iranian version of the questionnaire is used, which is based on the Olweus bullying questionnaire.

Results: The bullying rates at elementary, middle school, and high school are estimated at $25.1 \%, 17.8 \%$, and $39.7 \%$, respectively. Bullying rate is $7.13 \%$ among girls and $14.72 \%$ among boys. The results of our study show that the most important factors affecting bullying are gender, parental literacy, living with parents, type of school, economic and social status, educational level, and school size.

Conclusion: Due to the impact of policies at different educational levels, policymakers should pay special attention to perform bullying control programs at the school level based on the school environment variables, and policies in this area should be designed, reviewed, and modified.

\section{Background}

Academic education is a platform in which training, cultural, and moral principles are developed and then expanded to the desired level. Among these, the role of the school as a place for teaching and promoting these principles, is quite evident, in a way that students learn law-abiding in this environment and become socialized. However, one of the major challenges always faced by schools is bullying (1). Bullying in school is known as one of the problematic behaviors of adolescence that has recently attracted the attention of many researchers and experts and becomes the focus of many studies (2-5).

The results of previous studies in this regard indicates that the prevalence rate of bullying among students studying in different countries is close to $50 \%$ (6, 7). The prevalence of bullying among adolescents was estimated as $8 \%$ in Germany, $29.9 \%$ in the United States, $30 \%$ in Italy, $40 \%$ in Korea, $20 \%$ in the United Arab Emirates, and $39 \%$ in Oman $(8,9)$. Accordingly, this statistic varies from 22 to $55 \%$ in Iran $(10,11)$, all of which show a significant increase in bullying, so some students are victims of bullying due to their characteristics (7). Evidence shows that intense to persistent bullying can lead to long-term problems besides momentary dissatisfaction. Moreover, adolescents who are bullied at school are at higher risk of persistent upset and lack of self-esteem, and those who bully learn that they can abuse others through their power and force them to do whatever they want (12).

A study published in the Journal of the American University of Pediatrics by Surandar et al. (2009) examined the consequences of early puberty in children who were bullied at young age. Correspondingly, the results of this study showed that the occurrence of bullying behavior and the victim's behavior both increase the likelihood of psychiatric disorders among adults. The most interesting group consisted of those students who were frequently both bullying and victims of that. These individuals were classified as having a $30 \%$ chance of developing a psychiatric disorder, an $11.5 \%$ chance of being antisocial, and an approximately $30 \%$ of becoming clinically and mentally ill (13).

Bullying is an intentional aggression or harassment that is repeatedly perpetrated by an individual or a group of people over a period and manifests itself in forms of physical, verbal, and emotional behaviors. Additionally, this violence can be intrapersonal (violence against oneself), interpersonal, and collective. As well, the nature of acts of violence includes physical, sexual, psychological violence types or deprivation and ignorance (14-16). Olweus, as a pioneer in studying bully behavior, defined it as a subset of aggressive behaviors that can be expressed in verbal (such as insulting and calling people by titles), physical (such as hitting, kicking, and taking other's property), and psychological (expelling from the group and creating rumors against the victim) forms (17).

All researchers in the field of developmental psychology confirm that bullying in school is a form of physical, sexual, and psychological harassment of a student or students that occurs repeatedly against another student over a period. Bullying starts in elementary school and then intensifies in middle school in following years. But from the ninth grade onwards, a declining trend can be observed. Of note, physical bullying is more common among younger students. Meanwhile, among older students, bullying is mostly performed both verbally and psychologically (18-20).

However, it should be noted that bullying is a multidimensional issue that can be affected by a variety of personal, family, social environment, and social and economic pressures. Although the effects of some factors such as having aggressive parents, family disorders, and heredity on developing bully behavior are undeniable in this regard, most of the behavior is acquired and learned. Previous studies showed that in most cases, effective and strong upbringing can cover the effects of inheritance. Children who are bullies can have different roles, including (a) aggressors/harassers, (B) victims, (C) aggressors who are victims, and (d) passive observers (20). The occurrence of aggressive and violent behaviors in adults has its roots in their childhood and adolescence, many of which can be controlled using prevention programs from an early age. Criminals (childhood bullies) mostly tend to increase aggression and domestic violence in their adulthood (11). In this regard, Research has shown the negative impacts of school violence on both internalizing (e.g., depression) and externalizing (e.g., delinquency) children $(12,21)$. Bullying was indicated to be associated with social, physical, and psychological factors. Notably, it is more common in boys than girls in general, and bullying boys usually harass both boys and girls, but bullying girls bully their girl mates $(7,22)$.

The importance of bullying is not only in its prevalence, but also in the ambiguity of its recognition in society. Therefore, conducting more studies in this field can lead to obtain better understanding on the meaning of this word and the effective methods on its prevention. Understanding the context in which bullying occurs can help to plan for the adoption of prevention policies and programs. Therefore, the present study attempted to investigate the prevalence of bullying and its effective factors in adolescents aged between 10 and 18 years old in Kerman, in 2020.

\section{Methods}




\section{Study design}

This was a cross-sectional study. The study population included all the students aged between 10 and 18 years old at three academic grades in schools of Kerman, in 2020.

\section{Sampling and participants}

In this study, multi-stage sampling was used. At the first stage (stratified sampling), the selected schools were classified based on the students' gender and the type of classification was based on the geographical districts of Kerman, the number of schools in each group, and the relative share of girls and boys in each area. At the second stage, based on the list of the students in each school, they were selected by simple random sampling using a random number table. Considering the number of grades, we performed the relativity distribution and then 3 grades were selected. As a result, 1100 students ( 560 boys and 540 girls) were selected from elementary schools, secondary schools, and high schools in Kerman, Iran, in 2020. Because some potential confounders may be present at different levels, middle school students (14-year-old subjects) were selected from junior high schools as the sampling framework.

\section{Instruments}

To investigate the prevalence of bullying behavior in the selected schools, the Iranian version of the Rezapour et al.'s questionnaire was used, which is based on the Olweus bullying questionnaire. According to the objectives of the study, only those questions measuring the prevalence of bullying and victimization, were asked. The students were also asked to indicate the number of times they had victimized or bullied in the past 2 or 3 months in the questionnaire.

\section{Revised Questionnaire of Bully / Victim of Olweus (OB / VQ-R)}

The initial Olweus questionnaire (Olweus, 1986) has 40 items and is scored on a 5-point scale, but its revised and abbreviated questionnaire (Olweus, 1998) has 28 items. The bully/ victim questionnaire mainly asks students if they have "bullied others in the past few months, or have been bullied by others." Students are asked those questions that could best reflect their way of thinking or feeling during the past 2 or 3 months. Of note, the Olweus questionnaire (Olweus, 2002) is the most important and widely used sale of bullying worldwide, the validity and reliability of which have been confirmed in several studies (1, 23-25). Cronbach's alpha coefficient of 0.86 indicates the desirable and acceptable reliability of this questionnaire for assessing bullying among children and adolescents. In the present study, the reliability of this questionnaire was obtained by a test-retest methodology using Cronbach's alpha coefficient as 0.70 (26)

\section{The questionnaire used in this study consists of 2 parts}

1. Demographic information of the participants

2. Questions related to the victim (items 1 to 14) and bullying (items 15 to 18)

Part 1: This section included demographic information of the individuals and school level factors.

The level of students' economic and their social status were constructed using principal component analysis (PCA), which has been used in some other studies on bullying behaviors. In our study, several measurements were made of a combination of the available data on each family economic status (e.g., house characteristics) and parents' educational level and employment status. This combination was expected to better explain the level of students' economic and their social status and also to minimize the risk of observing multiple correlations in subsequent multivariate analyses. Economic level and social status indexes, in the form of the composite $z$ score, were extracted as the first major components with the highest eigenvalue, and they were then used to explain the economic and social statuses of the included students adequately (61\% of the variance in the measured socio-economic indicators). The score of the relevant economic and social status was classified into five categories (from low SES $=1$ to high level SES $=5$ ) and then used in the dimensional regression analysis. Moreover, the following variables were used in PCA: parents' educational levels (illiterate $=1$ to faculty members $=6$ ), parents' employment status (employed versus unemployed), home ownership (owner versus tenant), number of rooms per capita and having a private room (yes versus no), the amount of pocket money, and the number of family members.

Part 2: Item 1 has a general reference to victimization. Items 2, 8, and 9 are related to verbal victims. Items 3 and 5 are associated with communicative or emotional victims. Items 4, 6, and 7 are related to physical victims. Item 10 is related to cyber victims. Item 11 is related to other victims. Items 12 , 13 , and 14 describe the characteristics of a victim. Item 15 is a general reference to bullying. Items 16, 22, and 23 are related to verbal bullying. Items 17 and 19 are associated with communicative or emotional bullying. Items 18,20 , and 21 are related to physical bullying. Item 24 is related to cyber bullying. Item 25 is related to other cases of bullying. Finally, items 26,27 , and 28 describe the characteristics of bully subjects. Cutting points of 2 or 3 times a month are recommended as the most appropriate criterion for being a victim or a bully.

\section{Data collection}

Three teams experienced in bullying surveys were trained in a one-day workshop to review the objectives of this study and techniques of data collection. The team members were responsible for gathering the required information. Questions on school characteristics were answered by school principals, and items about bullying, victimization, and personal information were answered by the students. The students who were randomly selected (using a table of random numbers) from each class were then gathered in a single room and the questionnaires were distributed among them. The questionnaire was generally read by a facilitator to help the students in selecting the right option. Afterward, data were collected within 8 weeks from November 2019 to January 2020 . Notably, all the data collection steps were monitored by the lead researcher. 
To prevent bias caused by social undesirability, it was significantly controlled using a sealed ballot box. The students were assured that their answers would be cast in the ballot box without being handed over to the respondent. Conscious written consent was also obtained from all the respondents and they were free to leave the study at any desired time.

\section{Data Analysis}

Descriptive statistics were used to present the general characteristics of the selected schools and students (age, gender, students' educational level, parents' educational level, employment status of parents, etc.). Since the prevalence of bullying and victimization is a counting variable with high variability, in this study, the negative multiple regression model (backward method) was used to analyze the obtained data. Briefly, a mixed-effect negative binomial regression model with an independent variance-covariance structure was used as the final multivariate analysis in a generalization of the Poisson model.

To determine the final multivariate model, at first, we performed the univariate negative binomial regression analysis to measure the non-mediated effects of some factors on bullying behavior. Thereafter, as shown in Table 1, those variables with a significance level of less than 0.20 in the univariate analysis were simultaneously entered into negative binomial regression analysis with a multivariate mixed effect. In addition, each one of the main study criteria (e.g., perceived parental control) was adjusted for other variables (such as gender, SES, level of nutritional knowledge, media advertising, and perceived selfefficacy) in the model.

The minimum criteria measures of Akaike's and Schwarz's Bayesian information (namely AIC and BIC) were used to evaluate the good fit of the final model. Probability ratio test was also used as a criterion for applying the 2-level negative multiple regression model instead of using the negative multiple regression model. Subsequently, to better fit the model, the residual standard analysis was performed using the deviation and Pearson method. Finally, all the collected data were analyzed using SPSS v. 16.

\section{Ethical considerations}

The study permit was obtained from the Kerman Education Department. Informed consent was also obtained from the parents of all the students included. The needed data were collected using an anonymous self-report in the classroom by a trained researcher. The objectives and relevance of the study as well as the confidentiality of the students' responses were explained to them. The students were also informed about that the questionnaire completion was not mandatory. It is noteworthy that there was no time limit for completing the questionnaire and the average time to complete the questionnaires was about half an hour.

This project was approved with the code IR.KMU.REC.1397.568 on 2019/03/11 (date) by the ethics committee of Kerman University of Medical Sciences.

\section{Findings}

Table 1 shows both the percentage and frequency of variables of the individuals as well as the characteristics of the schools under study. In this study, 1100 students were enrolled and the response rate was 100\%, among whom 540 (49.1\%) subjects were boys and 560 (50.9\%) subjects were girls. Of the studied schools, 877 (79.7\%) schools were public and 223 (20.3\%) were non-profit schools. Additionally, 420 students were studying in primary school, 374 students in middle school, and 603 students in high school. Moreover, among the studied schools, 510 had health promotion programs and in 590 schools, health promotion programs were not implemented. Other variables, including pocket money (in Iranian Rials), homeownership, having a private room, family members, living with parents, educational and employment statuses of parents, having health educator, principal's experiences, having counselors, and number of bullying per week are presented in Table 1.

Using logistic regression model and considering the moderating variables, the results of this study show that the gender variable has a significant relationship with verbal, physical, and some other types of bullying, in a way that the chance of verbal, physical, and other types of bullying is $2.08,1.89$, and 2.22 times more among boys than girls, respectively. The results related to the variables modulating verbal, physical, and other types of bullying also show that those schools with health-promoting programs had a 1.45, 1.70, and 2.51 higher chance of developing verbal, physical, and other types of bullying than the schools without them. The moderating variables of both types of verbal and physical bullying have a significant relationship with the variable of studying level, in a way that the chances of verbal and physical bullying occurring in middle and high schools ( 0.69 and 0.65$)$ and ( 0.22 and 0.48$)$ were found to be lower than the chance on primary schools. The moderating variables of verbal and other types of bullying showed a significant relationship with the variable of living with other family members other than parents. Accordingly, the probability of verbal and other types of bullying in children living with other family members than the student living with both parents was estimated at 2.12 and 6.79 times higher, respectively. Additionally, the moderating variable of physical bullying was indicated to have a significant relationship with the variables of living with one of the parents and living with other family members. In this regard, the probability of physical bullying in living with one parent and other family members was estimated at 2.66 and 4.53 times higher than living with both parents, respectively. The results show that no significant relationship exists between moderator and independent variables such as type of school, presence of counselor, principal's experience, number of students, and the factors related to economic and social statuses (including having private room, the amount of pocket money, parents' educational levels, room per person, employment status, number of family members, and monthly family income) ( $P$ value $>0.05)$ (Table 2).

Using the multi logistic regression model, the results of this study indicate that the moderator variable of bullied and bully persons have a significant relationship with the variable of gender, so that the probability of bullying and being bullied is 2.36 times higher among boys than girls. With respect to the variable of schools providing health-promoting programs, a significant relationship was found with the moderator variable of emotional bullying, indicating that emotional bullying is 1.80 times more likely to occur in the schools with health-promoting programs than the schools without them. In the current study, the results demonstrate that the modulator variables of emotional bullying and being bullied have a significant relationship with the variable of the presence of counselors in schools, in a way that the chances of emotional bullying and being bullied were calculated to be 1.65 and 2.92 times higher in the schools 
with counselors, respectively. A significant relationship was also observed between the moderator variable of emotional bullying and the variable of educational level, in a way that the probability of the occurrence of emotional bullying in the middle and high schools is 0.35 and 0.44 times lower than the elementary school, respectively. As well, the chance of bullying and being bullied in the middle school is 0.37 less than this chance in elementary school. The results show that the moderating variable of emotional bullying has a significant relationship with the variable of living with parents. In this regard, the probability of emotional bullying in students living with one parent or living with other family members is 2.02 and 2.95 times higher than that of the students living with both parents. There is no significant relationship between the variables regulating emotional bullying and being bullied and the variables of school type, number of students, school's principal's experience, and economic and social statuses (P value>0.05) (Table 3 ).

The results obtained using the logistic regression model showed that all the moderating variables of the perpetrator of verbal, physical, and cyber bullying were significantly related to the following variables: gender, health-promoting schools, educational levels, living with other family members, and low economic level and social status ( $P$ value $<0.05$ ). With respect to the variable of gender, the chances of boys committing verbal, physical, and cyber bullying were found to be $3.27,8.59$, and 15.72 times higher than girls, respectively. In terms of the variable of the schools with health-promoting programs, the chance of verbal, physical, and cyber bullying was estimated as $1.71,2.18$, and 5.32 times higher than in the schools without health promoting programs, respectively. Moreover, the probability of verbal and physical bullying high school students is 2.19 and 2.48 times higher than primary school students, respectively. As well, the probability of cyber bullying by the students studying in middle and high schools is 0.09 less and 5.99 higher than elementary school, respectively. The results show that the chance of committing cyber bullying by students living with one of their family members is 10.70 times higher than that of students living with both parents. Furthermore, the probability of the moderating variable of physical bullying by the students with low economic and social statuses was found to be 0.15 less than the students with higher economic and social statuses. According to the obtained results, no significant relationship was observed between moderating variables and other variables such as type of schools, presence of counselor, experience of the schools' principals, and number of students ( $P$ value> 0.05) (table 4).

The results of the multi logistic regression model showed that a significant relationship exists between the moderator variable of emotional bullying and the variable of gender, and also among the moderator variable of bullying and the variables of gender, middle school level, and living with other family members (P-value <0.05). In this regard, in terms of the variable of gender, the chance of emotional bullying was calculated to be 3.40 and 6.96 times higher in boys compared to girls. As well, based on educational level, the probability of bullying is 0.28 times lower among middle school students compared to elementary school students. In regard with the variable of living with other family members other than the parents, the probability of bullying among the students was observed to be 3.92 times higher than that of the students living with their parents. There was no significant relationship amongst the moderating variables of emotional bullying and type of school, schools with health-promoting programs, presence of counselor, the schools' principal experience, number of students, and their economic and social statuses (P-value> 0.05). (Table 5)

\section{Discussion}

Bullying in adolescence is considered as a global problem and a public health concern due to causing some consequences such as mental illness, violence, and tobacco addiction during the adulthood. Also, bullying behavior is known as as an aggressive, unjustified, intentional and persistent behavior, which is characterized by a power imbalance between the victim and the bully person, and lead to negative psychological and social consequences in children and adolescents. Moreover, in some cases, it will create irreparable damages in their adulthood (27-29). Due to this issue, one of the significant problems in Iranian schools is the bullying behavior, so the present study was conducted in order to investigate the prevalence of bullying and victims' behaviors at all educational levels in schools of Kerman, located at southeastern Iran.

The results of our study demonstrate that the bullying rate in elementary, middle, and high schools is $25.1 \%, 17.8 \%$, and $39.7 \%$, respectively, which is very high. In girls and boys, this rate is $7.13 \%$ and $14.72 \%$, respectively. The results also show that the most important factors affecting bullying are gender, parental literacy, living with parents, type of school, economic and social statuses, educational level, and school size. Details and descriptions of these findings are provided below.

In our study, generally the bullying and victimization rates were $27.5 \%$ and $62.7 \%$, respectively. In terms of the type of school (elementary, middle, and high schools), this rate was estimated as $25.1 \%, 17.8 \%$, and $40 \%$; and $81 \%, 50.4 \%$, and $53.6 \%$, respectively. Additionally, the bullying rate among girls and boys was $13.3 \%$ and $41 \%$, respectively. Because no similar study has been conducted in the country, we cannot compare the obtained results with none of them. Bullying rates in Australia, the United Arab Emirates, Jordan, and South Africa are reported as $66.2 \%, 31 \%, 44.2 \%$, and $61 \%$, respectively. According to the international bullying rate that was surveyed in 47 countries, the average bullying rate was reported to be $29 \%$ (30-32).It can be said that the bullying rate in Iran is lower than the average rate of the studied countries. Studies conducted in Zanjan, Tehran, and Yazd provinces reported bullying and victimization rates of $9.8 \%$, $33.3 \%$, and $31 \%$; and $51 \%, 13 \%$, and $17 \%$, respectively, which are not consistent with our study (33-35). This can be due to various reasons, such as different cultures in various countries, as well as family educational level, and strictness in schools. Besides, in the study by Fujikawa et al., the results showed that the bullying rate was high in grades 3 to 6 , with $86 \%$ of students being bullied at least once during the last four weeks. Moreover, $66 \%$ of them faced recurring bullying and $37 \%$ reported repeated bullying in various forms (36). The results of the study by Rozemarijn van der Ploeg showed that the bullying rate is $25 \%$ and $21.6 \%$ among students (37). The reasons for the increase in bullying rate in higher education levels is due to the economic and psychological conditions of society, feeling powerfulness in students, and the increase of pressures of family. It was suggested that policymakers and officials can reduce the prevalence of bullying by providing support packages for needy families and holding free classes for their students.

In the present study, bullying has several dimensions, including verbal, physical, emotional, cyber, and other forms. The results of our study show that the rate of verbal bullying is higher among all the students in the studied schools. Verbal bullying is more common among the students of elementary school than in other grades. Additionally, physical bullying was found to occur more in high school than in other grades. In the study by Rezapour et al., the results presented that the rate of verbal bullying among students is $7.7 \%$ higher than the other dimensions of bullying (38). In a study conducted in Pakistan, the results showed 
that physical bullying has increased among students with higher educational level and verbal bullying also occurs more among those with lower educational levels (39).

Our study propose that the factors affecting bullying can vary from one aspect to another. In this regard, a significant relationship was observed between the individual and school factors, including gender, living with parents, educational level, and health-promoting schools, and the prevalence of bullying. Of note, verbal bullying is lower in girls than in boys. Meanwhile, a study in China found that girls are less likely to have verbal bullying in comparison to boys. In addition, in a study performed in Portugal, it was shown that the rates of both bullying and being bullied are higher in boys than girls (40), which was consistent with the results of our study. Accordingly, this can be due to the physiological behaviors and characteristics of girls and their role in society, which makes violent behaviors less common among them. It is suggested that school counselors should communicate more with male students and prevent bullying by them in schools. Schools can also consider integrated mental health measures for their students, and the viewers who are someway involved in bullying can be trained to control bullying situations.

In the present study, one of the factors at the school level is that schools should have a health-promoting program, because the extent of bullying and being bullied in these schools becomes significant in verbal, physical, and emotional aspects. In this way, bullying behavior is more common in health-promoting schools. A report published by the World Health Organization and the Tao Xu's study suggested that health-promoting schools could reduce bullying behaviors among students $(41,42)$, which is inconsistent with the results of our study. The reasons for this issue can be the lack of empowerment programs for students, staff, parents, and educators in the field of health-promotion concepts for adolescents and the youth in the domain of health-promoting schools, lack of the increased student participation in high-risk behaviors, lack of a model and a mechanism proposed for creating a national network of health-promoting schools in the country, different cultures of Iranian schools, lack of designing serious educational curriculum regarding bullying among students, and the lack of understanding on the practical goals of this project by the operators. Therefore, it is suggested that health-promoting schools can increase student participation through involving them in practical programs, paying special attention to the curriculum, providing a lively environment for students, identifying the real needs of students, understanding the capabilities of each student, avoiding from competition and psychological tensions in schools, building new paths for participation, and increasing student interest to ensure the success of such projects. The variables of economic and social statuses, the experience of schools' principals, and the presence of counselors were not significant, and other studies could not establish a relationship between these variables and bullying, which is in line with the results of our study. Furthermore, it was shown that family can have great effects on controlling and preventing high-risk bullying behaviors, and by educating parents, this behavior can be prevented to some extent $(35,43,44)$.

\section{Strengths and limitations}

The sample size of the present study was significant. It is one of the few studies conducted in all three levels of education (elementary, middle, and high schools) in Iran and allows the comparison based on the prevalence of bullying at these three levels. So, its results can be used to help in reducing and preventing bullying in schools systematically. One bias of the study was the consultation and communication of the included individuals with each other during the responding process. In order to eliminate this bias, before distributing the questionnaire, the researcher established a distance between the studied students and then gave them some explanations on the prohibition of consulting. Iran is a country with wide cultural diversities and ethnicities, which limit the generalizability of the results of the present study to other populations. As well, the results of this study cannot be generalized to the entire population of Iran and more studies performed in other ethnicities and cultures are required. Bullying behavior can also have a cultural and ethnic background, and this generalization should be performed with caution. There are several tools used for the investigation of bullying. In the current study, we used the instrument provided by Olweus, and if other bullying instruments perform better, they can be used in future studies.

\section{Conclusion}

The present study aimed to measure bullying prevalence among individuals with different levels and schools in one of the provinces of Iran. The results of our study show that the rate of bullying in Iran has increased compared to previous years, but it is lower compared to other countries. Among the most important factors affecting the prevalence of bullying at the individual and school levels, we can mention gender, educational level, parental literacy, living with parents, economic and social status, and health-promoting schools. Considering the policies at different levels, policymakers should pay special attention to schoollevel bullying-control programs, and some policies should be designed in this regard, reviewed, and then modified in relation to school environmental variables for bullying behavior. Policymakers can also make a hidden curriculum by creating an environment in the school that is free of violence and bullying through the relationships between students and staff and between parents and staff and through in-school programs, in order to reduce bullying at school level.

\section{Abbreviations}

OB / VQ-R: Revised Questionnaire of Bully / Victim of Olweus; PCA: Principal Component Analysis; AIC: Akaike Information Criterion; BIC: Bayesian Information Criterion.

\section{Declarations}

\section{Ethics approval and consent to participate}

This project was approved with the code IR.KMU.REC.1397.568 on 2019/03/11 (date) by the ethics committee of Kerman University of Medical Sciences.

\section{Consent for publication}

Not applicable. 


\section{Availability of data and materials}

The data that support the findings of this study are available from the corresponding author, [SMKS], upon reasonable request.

\section{Competing interests}

The authors declare no conflict of interest.

\section{Funding}

This study was funded by Kerman University of Medical Science (IR.KMU.REC.1397.568). The funding source was not involved in conducting the research, analyzing the data, or writing the final manuscript.

\section{Authors' contributions}

The study was designed and conducted by VYF, SR, and SMKS. MA carried out the analysis, and VYF, SMKS, MA analyzed and interpreted the obtained data. SMKS drafted the manuscript, and both VYF and SR revised and approved the final manuscript.

\section{Acknowledgement}

The authors would like to thank Dr Nozar Nakhaei and all the participants and contributors in this study.

\section{References}

1. Papanikolaou M, Chatzikosma T, Kleio K. Bullying at School: The role of family. Procedia - Social and Behavioral Sciences. 2011;29:433-42.

2. JW P, S H. Traditional and nontraditional bullying among youth: A test of general strain theory. Youth \& Society. 2011;43(2):727-51.

3. Lapidot-Lefler N, Dolev-Cohen M. Comparing cyberbullying and school bullying among school students: prevalence, gender, and grade level differences. Social Psychology of Education. 2014;18(1):1-6.

4. Shujja S, Atta M, Shujjat JM. Prevalence of Bullying and Victimization among Sixth Graders with Reference to Gender, Socio-economic Status and Type of Schools. Journal of Social Sciences. 2014;38(2):159-65.

5. Urra Canales M, Acosta Oidor C, Salazar Baena V, Jaime Ruiz E. Bullying. Description of the roles of victim, bully, peer group, school, family and society. 2018. 2018;7(3):22.

6. Black S, Weinles D, Washington E. Victim Strategies to Stop Bullying. Youth Violence and Juvenile Justice. 2010;8(2):138-47.

7. Wong DSW, Lok DPP, Wing Lo T, Ma SK. School Bullying Among Hong Kong Chinese Primary Schoolchildren. Youth \& Society. 2008;40(1):35-54.

8. Abdulsalam AJ, Al Daihani AE, Francis K. Prevalence and Associated Factors of Peer Victimization (Bullying) among Grades 7 and 8 Middle School Students in Kuwait. International Journal of Pediatrics. 2017;2017:1-8.

9. Magklara K, Skapinakis P, Gkatsa T, Bellos S, Araya R, Stylianidis S, et al. Bullying behaviour in schools, socioeconomic position and psychiatric morbidity: a cross-sectional study in late adolescents in Greece. Child Adolesc Psychiatry Ment Health. 2012;6(1):8-.

10. Garmaroudi G, Mohammad K, Omidvari S, Jafarpour S. Prevalence of Bullying and its Associated Factors among Iranian Middle School Students. Health Education and Health Promotion. 2014;2:9-20.

11. Kelishadi R, Heshmat R, Motlagh ME, Majdzadeh R, Keramatian K, Qorbani M, et al. Methodology and Early Findings of the Third Survey of CASPIAN Study: A National School-based Surveillance of Students' High Risk Behaviors. Int J Prev Med. 2012;3(6):394-401.

12. Farrington DP. Understanding and Preventing Bullying. Crime and Justice. 1993;17:381-458.

13. Kashfi SS, Jalilvand R. Identification and prevention of bullying in schools. Crime Prevention Studies Quarterly. 2019;14(50):83-109.

14. Mercy J, Dahlberg L, Zwi A. The world report on violence and health. Lancet. 2002;360:1083-8.

15. Nansel TR, Overpeck M, Pilla RS, Ruan WJ, Simons-Morton B, Scheidt P. Bullying behaviors among US youth: prevalence and association with psychosocial adjustment. JAMA. 2001;285(16):2094-100.

16. Olweus D. A profile of bullying at school. Educational leadership. 2003;60(6):12-7.

17. Olweus D. Bullying at School: Basic Facts and Effects of a School Based Intervention Program. Journal of child psychology and psychiatry, and allied disciplines. 1994;35:1171-90.

18. Beirami M, Kazemi S, Movahdy Y, Sepahvand R. Reducing Adolescent Rage Bullies: Study on Behavior Management Training Intervention. Armaghane danesh. 2016;21(9):900-13.

19. Pourmand F, Mohsenzadeh F, Ghaedniay Jahromi A. Association between family functioning, domestic violence and parent-child relation and the attitude of being victims of bullying among high school girls. Commonity Health. 2017;4(4):275-85.

20. Rahmani S, Yarmohammadzadeh P, Habibi Kalibar R. Explain the structural model bullying by perception of parent and personal characteristic. Journal of Applied Psychology. 2017;11(2):237-53

21. Olweus D. Bully/victim problems in school: Facts and intervention. European Journal of Psychology of Education. 1997;12(4):495.

22. Sepehrian azar F, Mohammadi N, Blootak H. The Study of Prevalence of Bullying and Comparing the Academic Achievement, Social Self- Efficacy and General Health of Adolescents with Bully and Ordinary Behavior. Scientific Journal Management System. 2015;1(2):32-23.

23. Baldry AC. Bullying in schools and exposure to domestic violence. Child abuse \& neglect. 2003;27(7):713-32. 
24. Lee, Cornell D. Concurrent Validity of the Olweus Bully/Victim Questionnaire. Journal of School Violence. 2010;9:56-73.

25. Solberg ME, Olweus D. Prevalence estimation of school bullying with the Olweus Bully/Victim Questionnaire. 2003;29(3):239-68.

26. Rezapour M, Soori H, Khodakarim S. Testing Psychometric Properties of the Perpetration of Bullying and Victimization Scales with Olweus Bullying Questionnaire in Middle Schools. Journal of Safety Promotion and Injury Prevention. 2014;1(4):212-21.

27. Albaladejo-Blázquez N, Ferrer-Cascales R, Ruiz-Robledillo N, Sánchez-SanSegundo M, Fernández-Alcántara M, Delvecchio E, et al. Health-Related Quality of Life and Mental Health of Adolescents Involved in School Bullying and Homophobic Verbal Content Bullying. International journal of environmental research and public health. 2019;16(14).

28. Fenny O, Falola MI. Prevalence and Correlates of Bullying Behavior Among Nigerian Middle School Students. International journal of offender therapy and comparative criminology. 2020;64(5):564-85.

29. Maïano C, Aimé A, Salvas MC, Morin AJ, Normand CL. Prevalence and correlates of bullying perpetration and victimization among school-aged youth with intellectual disabilities: A systematic review. Research in developmental disabilities. 2016;49-50:181-95.

30. Morodi R, Merwe EVd, Ladikos A, Prinsloo J, Ovens M, Neser J. The victims of bullying in schools. 2004;17(3):28-47.

31. Rigby K. Bullying in Australian schools: the perceptions of victims and other students. Social Psychology of Education. 2017;20:1-12.

32. Rigby K, Haroun D, Ali E. Bullying in Schools in the United Arab Emirates and the Personal Safety of Students. Child Indicators Research. 2019;12(5):166375 .

33. Garmaroudi G, Mohammad K, Omidvari S, Jafarpour Sjhe, Promotion H. Prevalence of bullying and its associated factors among Iranian middle school students. Health Education and Health Promotion. 2014;2(3):-.

34. Mohammad Ali Mazaheri T, Smaeil S, Mostafa V. Studying Nature and Prevalence of Bullying in Zanjan's Rural Secondary Schools. Educational Psychology. 2015;11(36):17-38.

35. Najarzadegan MR, Fard M, Shooshtari M, Shahriarfar M, Bidaki R, Zarepur E. A Survey on Standardization of Olweus Bullying Questionnaire in Iran. Focus on Sciences. 2016;2:1-10.

36. Fujikawa S, Mundy LK, Canterford L, Moreno-Betancur M, Patton GC. Bullying Across Late Childhood and Early Adolescence: A Prospective Cohort of Students Assessed Annually From Grades 3 to 8. Academic pediatrics. 2020.

37. Ploeg R, Steglich C, Veenstra R. The way bullying works: How new ties facilitate the mutual reinforcement of status and bullying in elementary schools. Social Networks. 2019.

38. Rezapour M, Khanjani N, Mirzai M. Exploring associations between school environment and bullying in Iran: Multilevel contextual effects modeling. Children and Youth Services Review. 2019;99:54-63.

39. Khawar R, Malik F. Bullying behavior of Pakistani pre-adolescents: Findings based on olweus questionnaire. Pakistan Journal of Psychological Research. 2016;31:23-43.

40. Coelho V, Sousa V, Marchante M, Brás P, Romão A. Bullying and cyberbullying in Portugal: Validation of a questionnaire and analysis of prevalence. School Psychology International. 2016;37.

41. WHO. Global standards and indicators for health promoting schools and their implementation guidance.: World Health Organization; 2020. Available from: https://www.who.int/news-room/articles-detail/global-standards-and-indicators-for-health-promoting-schools-and-their-implementation-guidance. Accessed 15 October 2020.

42. Xu T, Tomokawa S, Gregorio ER, Jr., Mannava P, Nagai M, Sobel H. School-based interventions to promote adolescent health: A systematic review in lowand middle-income countries of WHO Western Pacific Region. PloS one. 2020;15(3):e0230046.

43. Yazdi Feyzabadi V, Keshavarz Mohammadi N, Omidvar N, Karimi-Shahanjarini A, Nedjat S, Rashidian A. Factors Associated With Unhealthy Snacks Consumption Among Adolescents in Iran's Schools. International journal of health policy and management. 2017;6(9):519-28.

44. Yazdi-Feyzabadi V, Mehrolhassani MH, Zolala F, Haghdoost A, Oroomiei N. Determinants of risky sexual practice, drug abuse and alcohol consumption in adolescents in Iran: a systematic literature review. Reproductive health. 2019;16(1):115.

\section{Tables}

Table 1: A description of individual and school characteristics 


\begin{tabular}{|c|c|c|c|}
\hline Level & Variable & Frequency & Percent \\
\hline \multirow[t]{43}{*}{ Individual } & Sex & & \\
\hline & Female & 560 & 50.9 \\
\hline & Male & 540 & 49.1 \\
\hline & Degree & & \\
\hline & Primarily & 420 & 38.2 \\
\hline & Elementary & 374 & 34 \\
\hline & Secondary & 306 & 27.8 \\
\hline & pocket money & & \\
\hline & None & 239 & 21.8 \\
\hline & 500000 & 748 & 68.5 \\
\hline & $500000-1000000$ & 91 & 9.2 \\
\hline & 1000000 & 19 & 1.9 \\
\hline & House Ownership & & \\
\hline & Owner & 328 & 29.9 \\
\hline & Tenant & 761 & 69.3 \\
\hline & Dorm & 9 & 0.8 \\
\hline & Private room & & \\
\hline & Yes & 571 & 52.2 \\
\hline & No & 523 & 47.8 \\
\hline & Family member number & & \\
\hline & 4 & 607 & 55.4 \\
\hline & $5-8$ & 478 & 43.4 \\
\hline & 8 & 14 & 1.3 \\
\hline & Life with parents & & \\
\hline & Double parents & 994 & 90.5 \\
\hline & single parents & 70 & 6.4 \\
\hline & Other & 34 & 3.1 \\
\hline & Father education & & \\
\hline & Illiterate & 64 & 5.9 \\
\hline & Under diploma & 357 & 32.9 \\
\hline & Diploma & 353 & 32.5 \\
\hline & College degree & 312 & 28.7 \\
\hline & Mother education & & \\
\hline & Illiterate & 75 & 6.8 \\
\hline & Under diploma & 308 & 28.1 \\
\hline & Diploma & 428 & 39.1 \\
\hline & College degree & 285 & 26 \\
\hline & Father employment & & \\
\hline & Unemployed & 107 & 9.9 \\
\hline & Employed & 975 & 90.1 \\
\hline & Mother employment & & \\
\hline & Unemployed & 787 & 71.6 \\
\hline & Employed & 312 & 28.4 \\
\hline $\mathrm{Sc}$ & School ownership & & \\
\hline
\end{tabular}

Page 9/18 


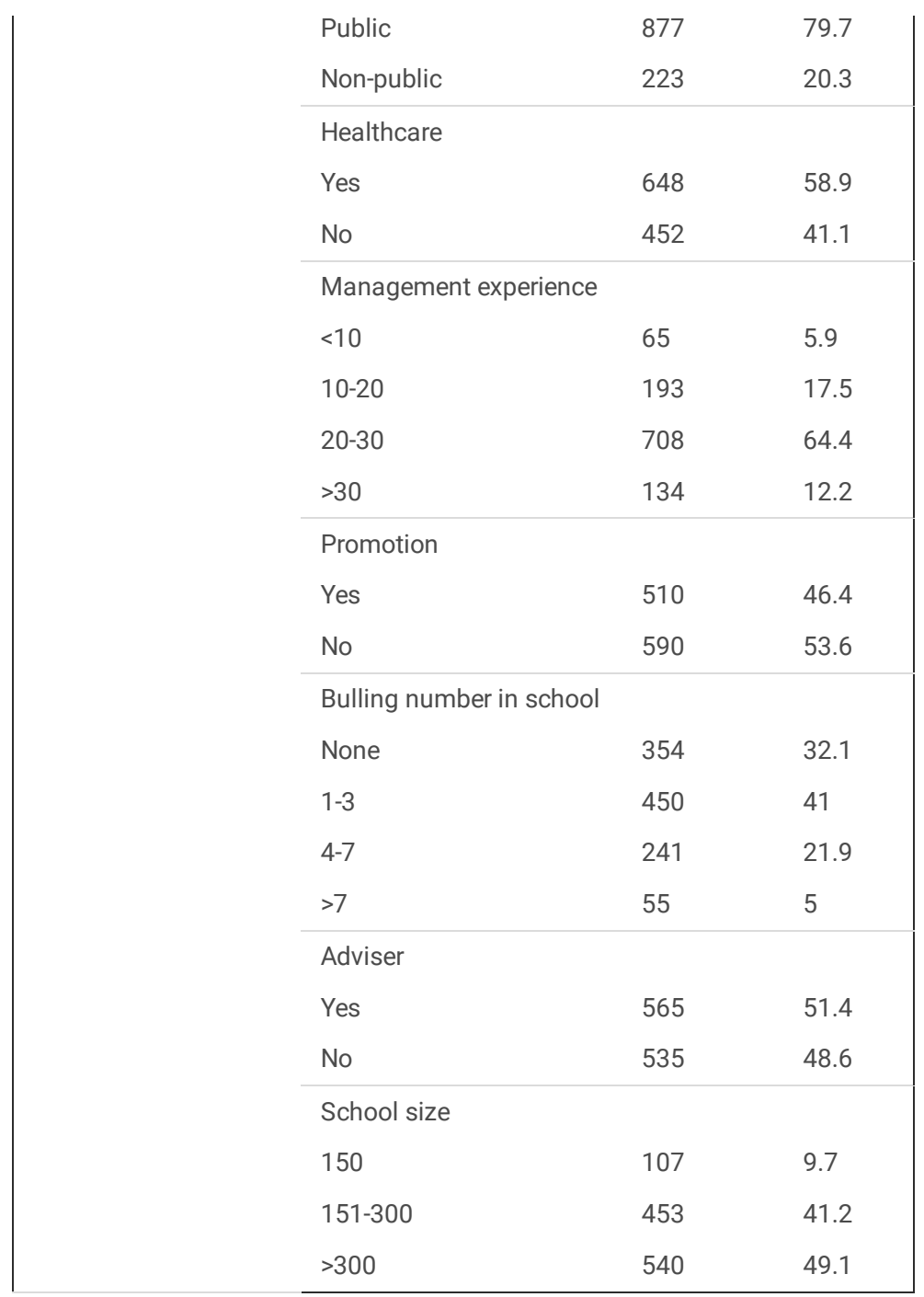

Table 2:The factors affecting on bullied using logistic regression model 


\begin{tabular}{|c|c|c|c|c|c|c|c|c|c|c|c|}
\hline \multirow[t]{2}{*}{ Variable } & \multicolumn{4}{|c|}{ Verbal bullied } & \multicolumn{4}{|c|}{ Physical bullied } & \multicolumn{3}{|c|}{ Other bullied } \\
\hline & $\beta$ & $\begin{array}{l}\text { Standard } \\
\text { error }\end{array}$ & $\begin{array}{l}\text { OR; } 95 \% \\
\text { CL }\end{array}$ & $P$ value & $\beta$ & $\begin{array}{l}\text { Standard } \\
\text { error }\end{array}$ & $\begin{array}{l}\text { OR; } 95 \% \\
\text { CL }\end{array}$ & $P$ value & $\beta$ & $\begin{array}{l}\text { Standard } \\
\text { error }\end{array}$ & OR; 95\% CL \\
\hline \multicolumn{12}{|l|}{$\begin{array}{l}\text { School } \\
\text { ownership }\end{array}$} \\
\hline \multirow{2}{*}{$\begin{array}{l}\text { Public } \\
\text { Non-public }\end{array}$} & \multirow{2}{*}{$\begin{array}{l}-0.11 \\
\text { Referent }\end{array}$} & \multirow{2}{*}{ Referent } & \multirow{2}{*}{$\begin{array}{l}0.88(-0.69 \\
-0.45) \\
\text { Referent }\end{array}$} & \multirow{2}{*}{$\begin{array}{l}0.68 \\
\text { Referent }\end{array}$} & \multirow{2}{*}{ Referent } & \multirow{2}{*}{$\begin{array}{l}5.99 \\
\text { Referent }\end{array}$} & \multirow{2}{*}{$\begin{array}{l}7.09(0.30- \\
3.61) \\
\text { Referent }\end{array}$} & \multirow{2}{*}{$\begin{array}{l}0.02^{\star} \\
\text { Referent }\end{array}$} & \multirow{2}{*}{ Referent } & \multirow{2}{*}{ Referent } & $\begin{array}{l}2.09(-2227.0 \\
-2255.86)\end{array}$ \\
\hline & & & & & & & & & & & Referent \\
\hline \multicolumn{12}{|l|}{ Sex } \\
\hline Female & Referent & Referent & Referent & Referent & Referent & Referent & Referent & Referent & Referent & Referent & Referent \\
\hline Male & 0.73 & 0.31 & $\begin{array}{l}2.08(0.43 \\
-\quad 1.03)\end{array}$ & $0.00 *$ & 0.64 & 0.47 & $\begin{array}{l}1.89 \\
(0.15- \\
1.13)\end{array}$ & $0.01 *$ & 0.80 & 0.81 & $\begin{array}{l}2.22(0.08- \\
1.52)\end{array}$ \\
\hline \multicolumn{12}{|l|}{ Promotion } \\
\hline Yes & 0.37 & 0.25 & \multirow{3}{*}{$\begin{array}{l}1.45(0.02 \\
-\quad 0.72)\end{array}$} & $0.03^{*}$ & 0.37 & 0.47 & \multirow{3}{*}{$\begin{array}{l}1.70 \\
(-0.01- \\
1.07) \\
\text { Referent }\end{array}$} & \multirow{3}{*}{$\begin{array}{l}0.05^{\star} \\
\text { Referent }\end{array}$} & \multirow{3}{*}{$\begin{array}{l}0.92 \\
\text { Referent }\end{array}$} & \multirow{3}{*}{$\begin{array}{l}1.04 \\
\text { Referent }\end{array}$} & \multirow{3}{*}{$\begin{array}{l}2.51(0.10- \\
1.73) \\
\text { Referent }\end{array}$} \\
\hline No & Referent & Referent & & Referent & Referent & Referent & & & & & \\
\hline & & & & & & & & & & & \\
\hline \multicolumn{12}{|l|}{ Adviser } \\
\hline Yes & 0.03 & 0.18 & $\begin{array}{l}1.04(-0.30 \\
-\quad 0.38)\end{array}$ & 0.81 & 0.03 & 0.51 & $\begin{array}{l}1.81(0.04 \\
-1.15)\end{array}$ & $0.03^{*}$ & 0.31 & 0.54 & $\begin{array}{l}1.36(-.47- \\
1.09)\end{array}$ \\
\hline No & Referent & Referent & Referent & Referent & Referent & Referent & Referent & Referent & Referent & Referent & Referent \\
\hline $\begin{array}{l}\text { Manager } \\
\text { experience } \\
<10\end{array}$ & Referent & Referent & Referent & Referent & Referent & Referent & Referent & Referent & Referent & Referent & Referent \\
\hline$<20$ & -0.07 & 0.29 & $\begin{array}{l}0.93(-0.69 \\
-\quad 0.55)\end{array}$ & 0.82 & -0.07 & 1.49 & $\begin{array}{l}1.75(-0.04 \\
-\quad 207)\end{array}$ & 0.06 & 0.64 & 1.60 & $\begin{array}{l}1.90(-1.00- \\
299)\end{array}$ \\
\hline 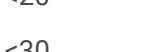 & -0.27 & 0.22 & (.0) & 0.35 & -0.27 & 0.50 & $2.07)$ & 0.95 & -0.03 & 0.78 & \\
\hline$<30$ & -0.45 & 0.28 & $\begin{array}{l}0.76(-0.85 \\
-\quad 0.30)\end{array}$ & 0.31 & -0.45 & 6.51 & $\begin{array}{l}0.96(-1.04 \\
-\quad 0.98)\end{array}$ & 0.06 & 15.27 & 4.93 & $\begin{array}{l}0.96(-1.64- \\
1.56)\end{array}$ \\
\hline & & & $\begin{array}{l}0.63(-1.34 \\
-\quad 0.42)\end{array}$ & & & & $\begin{array}{l}6.38(-0.14 \\
-\quad 3.85)\end{array}$ & & & & $\begin{array}{l}0.43(-2226.17 \\
-2256.72)\end{array}$ \\
\hline Degree & & & & & & & & & & & \\
\hline Primarily & Referent & Referent & Referent & Referent & Referent & Referent & Referent & Referent & Referent & Referent & Referent \\
\hline Elementary & -0.36 & 0.12 & $\begin{array}{l}0.69(-0.73 \\
--0.00)\end{array}$ & $0.04^{*}$ & -0.36 & 0.06 & $\begin{array}{l}0.22(-2.12 \\
--0.89)\end{array}$ & $0.00 *$ & -0.69 & 0.22 & $\begin{array}{l}0.49(-1.58- \\
0.19)\end{array}$ \\
\hline Secondary & -0.41 & 0.13 & $\begin{array}{l}0.65(-0.83 \\
-\quad-0.00)\end{array}$ & $0.04^{\star}$ & -0.41 & 0.15 & $\begin{array}{c}0.48(-1.35 \\
-\quad-0.08)\end{array}$ & $0.02^{\star}$ & 0.25 & 0.60 & $\begin{array}{l}1.28(-0.67- \\
1.17)\end{array}$ \\
\hline School size & & & & & & & & & & & \\
\hline 150 & Referent & Referent & Referent & Referent & Referent & Referent & Referent & Referent & Referent & Referent & Referent \\
\hline $151-300$ & Referent & Referent & Referent & Referent & Referent & Referent & Referent & Referent & Referent & Referent & Referent \\
\hline$>300$ & -0.00 & 0.17 & $\begin{array}{l}0.99(-0.36 \\
-0.34)\end{array}$ & 0.96 & -0.00 & 0.23 & $\begin{array}{l}0.84(-0.71 \\
-\quad 0.38)\end{array}$ & 0.54 & 0.12 & 0.47 & $\begin{array}{l}1.13(-0.68- \\
0.93)\end{array}$ \\
\hline Life with & & & & & & & & & & & \\
\hline Double & Referent & Referent & Referent & Referent & Referent & Referent & Referent & Referent & Referent & Referent & Referent \\
\hline Single & 0.19 & 0.33 & $\begin{array}{l}1.21(-0.34 \\
-0.73)\end{array}$ & 0.48 & 0.19 & 0.87 & $\begin{array}{l}2.66(0.33 \\
-1.62)\end{array}$ & $0.00 *$ & 0.00 & 0.62 & $\begin{array}{l}1.00(-1.22- \\
1.22)\end{array}$ \\
\hline $\begin{array}{l}\text { parents } \\
\text { Other }\end{array}$ & 0.75 & 0.73 & $\begin{array}{l}2.12(0.03 \\
-1.46)\end{array}$ & $0.03^{*}$ & 0.75 & 1.98 & $\begin{array}{l}4.53(0.65 \\
-\quad 2.36)\end{array}$ & $0.00 *$ & 1.91 & 3.36 & $\begin{array}{l}6.79(0.94- \\
2.88)\end{array}$ \\
\hline $\begin{array}{l}\text { Social and } \\
\text { economic } \\
\text { statue }\end{array}$ & & & & & & & & & & & \\
\hline lowest & Referent & Referent & Referent & Referent & Referent & Referent & Referent & Referent & Referent & Referent & Referent \\
\hline low & 0.02 & 0.44 & $1.02(-0.83$ & 0.95 & 0.02 & 0.36 & $0.56(-1.81$ & 0.37 & -0.97 & 0.32 & $0.37(-2.66-$ \\
\hline moderate & -0.07 & 0.38 & & 0.86 & -0.07 & 0.35 & & 0.38 & -0.38 & 0.51 & \\
\hline high & -0.09 & 0.38 & $\begin{array}{l}0.92(-0.89 \\
-0.74)\end{array}$ & 0.82 & -0.09 & 0.50 & $\begin{array}{l}0.51(-1.07 \\
-\quad 0.64)\end{array}$ & 0.77 & -1.05 & 0.27 & $\begin{array}{l}0.6 /(-1.8 /- \\
1.10)\end{array}$ \\
\hline
\end{tabular}




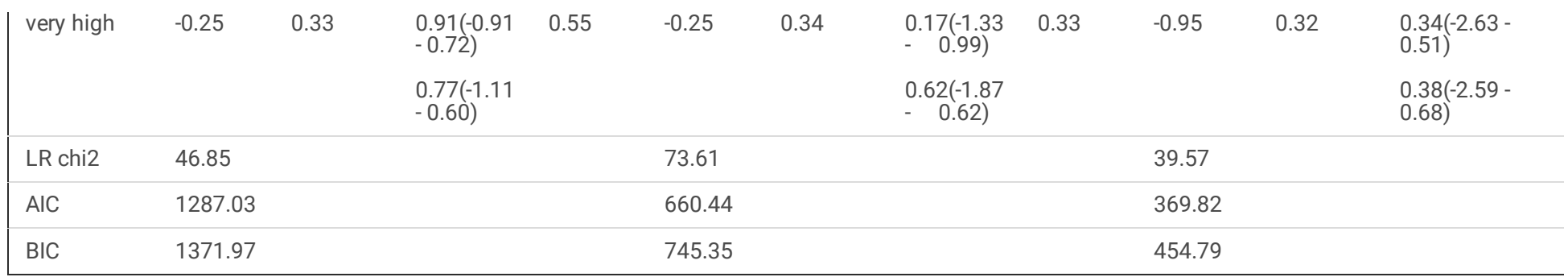

Coefficient 0.05

Table 3:The factors affecting on bullied using multi logistic regression model 


\begin{tabular}{|c|c|c|c|c|c|c|c|c|c|}
\hline \multirow[t]{2}{*}{ Variable } & \multicolumn{4}{|c|}{ Emotional bullied } & \multicolumn{5}{|c|}{ Bullied and buller } \\
\hline & $\beta$ & $\begin{array}{l}\text { Standard } \\
\text { error }\end{array}$ & OR; $95 \% \mathrm{CL}$ & $P$ value & $\beta$ & $\begin{array}{l}\text { Standard } \\
\text { error }\end{array}$ & OR; $95 \% \mathrm{CL}$ & & $P$ value \\
\hline \multicolumn{10}{|c|}{ School ownership } \\
\hline Public & 0.22 & 0.48 & $\begin{array}{l}1.25(-0.53- \\
0.97)\end{array}$ & 0.56 & 1.33 & 4.56 & $3.78(-1.03-$ & $3.69)$ & 0.27 \\
\hline Non-public & Referent & Referent & Referent & Referent & Referent & Referent & \multicolumn{2}{|l|}{ Referent } & Referent \\
\hline \multicolumn{10}{|l|}{ Sex } \\
\hline Female & Referent & Referent & Referent & Referent & Referent & Referent & Referent & & Referent \\
\hline Male & 0.22 & 0.22 & $\begin{array}{l}1.25(-0.12- \\
0.58)\end{array}$ & 0.20 & 0.85 & 0.99 & 2.36(0.02 - & 1.68) & $0.04 *$ \\
\hline \multicolumn{10}{|l|}{ Promotion } \\
\hline Yes & 0.59 & 0.78 & $1.80(0.19-\quad 0.99)$ & $0.00 *$ & 0.54 & 0.78 & $1.71(-0.35-$ & 1.43) & 0.23 \\
\hline No & Referent & Referent & Referent & Referent & Referent & Referent & Referent & & Referent \\
\hline \multicolumn{10}{|l|}{ Adviser } \\
\hline Yes & 0.50 & 0.36 & $1.65(0.07-\quad 0.92)$ & $0.02^{*}$ & 1.71 & 2.92 & $5.57(0.68-$ & 2.74) & $0.00 *$ \\
\hline No & Referent & Referent & Referent & Referent & Referent & Referent & Referent & & Referent \\
\hline \multicolumn{10}{|c|}{ Manager experience } \\
\hline$<10$ & Referent & Referent & Referent & Referent & Referent & Referent & Referent & & Referent \\
\hline$<20$ & 0.30 & 0.54 & $1.35(-0.48-1.08)$ & 0.45 & 0.17 & 0.94 & $1.18(-1.38$ & - & 0.82 \\
\hline$<30$ & 0.10 & 0.40 & $1.11(-0.60-0.81)$ & 0.77 & -0.28 & 0.58 & \multirow{2}{*}{$\begin{array}{l}0.75(-1.80 \\
1.23)\end{array}$} & \multirow{2}{*}{-} & 0.71 \\
\hline \multirow[t]{2}{*}{$>30$} & 0.09 & 0.62 & $1.09(-1.03-1.21)$ & 0.87 & 0.37 & 2.10 & & & 0.80 \\
\hline & & & & & & & $\begin{array}{l}1.44(-2.48 \\
3.22)\end{array}$ & - & \\
\hline \multicolumn{10}{|l|}{ Degree } \\
\hline Primarily & Referent & Referent & Referent & Referent & Referent & Referent & Referent & & Referent \\
\hline Elementary & -1.02 & 0.08 & $0.35(-1.47--0.57)$ & $0.00 *$ & -0.97 & 0.18 & $0.37(-1.91-$ & $-0.02)$ & $0.04 *$ \\
\hline Secondary & -0.81 & 0.11 & $\begin{array}{l}0.44(-1.31- \\
-0.30)\end{array}$ & $0.00 *$ & -1.00 & 0.21 & $\begin{array}{l}0.36(-2.17 \\
0.17)\end{array}$ & - & 0.09 \\
\hline \multicolumn{10}{|l|}{ School size } \\
\hline$<=150$ & Referent & Referent & Referent & Referent & Referent & Referent & Referent & & Referent \\
\hline $151-300$ & Referent & Referent & Referent & Referent & Referent & Referent & Referent & & Referent \\
\hline$>300$ & -0.06 & 0.19 & $\begin{array}{l}0.93(-0.47- \\
0.35)\end{array}$ & 0.76 & -0.13 & 0.40 & $\begin{array}{l}0.87(-1.04 \\
0.78)\end{array}$ & - & 0.77 \\
\hline \multicolumn{10}{|l|}{ Life with } \\
\hline Double parents & Referent & Referent & Referent & Referent & Referent & Referent & Referent & & Referent \\
\hline Single parents & 0.70 & 0.57 & $2.02(0.15-\quad 1.26)$ & $0.01^{\star}$ & 0.66 & 1.10 & $1.93(-0.45$ & - & 0.24 \\
\hline Other & 1.08 & 1.14 & $2.95(0.32-\quad 1.84)$ & $0.00 *$ & 1.35 & 2.45 & \multicolumn{2}{|c|}{$3.88(0.11-2.59)$} & $0.03^{*}$ \\
\hline \multicolumn{4}{|c|}{ Social and economic } & Referent & Referent & Referent & Referent & & Referent \\
\hline \multirow{5}{*}{$\begin{array}{l}\text { lowest } \\
\text { low } \\
\text { moderate } \\
\text { high } \\
\text { very high }\end{array}$} & -0.23 & 0.40 & $\begin{array}{l}0.79(-1.23- \\
0.76)\end{array}$ & 0.64 & 0.09 & 1.03 & $\begin{array}{l}1.10(-1.74 \\
1.93)\end{array}$ & - & 0.91 \\
\hline & -0.37 & 0.33 & & 0.43 & -0.16 & 0.80 & & & 0.86 \\
\hline & -0.40 & 0.32 & $\begin{array}{l}0.68(-1.32- \\
0.56)\end{array}$ & 0.40 & -0.20 & 0.78 & $\begin{array}{l}0.84(-2.01 \\
1.69)\end{array}$ & - & 0.83 \\
\hline & -0.08 & 0.46 & $\begin{array}{l}0.66(-1.35- \\
0.55)\end{array}$ & 0.87 & 0.50 & 1.61 & $\begin{array}{l}0.81(-2.09 \\
1.68)^{-}\end{array}$ & - & 0.60 \\
\hline & & & $\begin{array}{l}0.92(-1.06- \\
0.89)\end{array}$ & & & & $\begin{array}{l}1.66(-1.39 \\
2.41)\end{array}$ & - & \\
\hline Wald chi2 & 52.37 & & & & 32.63 & & & & \\
\hline
\end{tabular}




\begin{tabular}{|lll|} 
ICC & 5.48 & 5.15 \\
\hline AIC & 1005.84 & 335.48 \\
\hline BIC & 1090.77 & 420.45 \\
\hline
\end{tabular}

Coefficient 0.05

Table 4:The factors affecting on buller using logistic regression model 


\begin{tabular}{|c|c|c|c|c|c|c|c|c|c|c|c|}
\hline \multirow[t]{2}{*}{ Variable } & \multicolumn{4}{|c|}{ Verbal buller } & \multicolumn{4}{|c|}{ Physical buller } & \multicolumn{3}{|c|}{ Cybernetic buller } \\
\hline & $\beta$ & $\begin{array}{l}\text { Standard } \\
\text { error }\end{array}$ & $\begin{array}{l}\text { OR; } 95 \% \\
\mathrm{CL}\end{array}$ & $P$ value & $\beta$ & $\begin{array}{l}\text { Standard } \\
\text { error }\end{array}$ & $\begin{array}{l}\mathrm{OR} ; 95 \% \\
\mathrm{CL}\end{array}$ & $P$ value & $\beta$ & $\begin{array}{l}\text { Standard } \\
\text { error }\end{array}$ & OR; $95 \% \mathrm{CL}$ \\
\hline \multirow{3}{*}{$\begin{array}{l}\text { School } \\
\text { ownership } \\
\text { public } \\
\text { Non-public }\end{array}$} & & & & & & & & & & & \\
\hline & 0.09 & & $\begin{array}{l}1.10(-0.79- \\
0.98)\end{array}$ & & & & $\begin{array}{l}0.57(-1.90 \\
-0.81)\end{array}$ & & & & $\begin{array}{l}29(-3015.13- \\
3044.95)\end{array}$ \\
\hline & Referent & Referent & Referent & Referent & Referent & Referent & Referent & Referent & Referent & Referent & Referent \\
\hline \multicolumn{12}{|l|}{ Sex } \\
\hline Female & Referent & Referent & Referent & Referent & Referent & Referent & Referent & Referent & Referent & Referent & Referent \\
\hline Male & 1.18 & 0.75 & $\begin{array}{l}3.27(0.73 \\
-1.63)\end{array}$ & $0.00 *$ & 2.15 & 3.70 & $\begin{array}{l}8.59(1.30 \\
-2.99)\end{array}$ & 0.00 * & 2.75 & 14.73 & $\begin{array}{l}15.72(0.91 \text { - } \\
4.59)\end{array}$ \\
\hline \multicolumn{12}{|l|}{ Promotion } \\
\hline Yes & 0.54 & 0.43 & $\begin{array}{l}1.71(0.04 \text { - } \\
1.03)\end{array}$ & $0.03^{\star}$ & 0.78 & 0.88 & $\begin{array}{l}2.18(-0.01 \\
-1.57)\end{array}$ & $0.0^{*}$ & 1.67 & 4.63 & $\begin{array}{l}5.32(-0.03- \\
3.37)\end{array}$ \\
\hline No & Referent & Referent & Referent & Referent & Referent & Referent & Referent & Referent & Referent & Referent & Referent \\
\hline Adviser & & & & & & & & & & & \\
\hline & 0.06 & 0.25 & $\begin{array}{l}1.06(-0.39 \\
-0.52)\end{array}$ & & -0.06 & & $\begin{array}{l}0.93(-0.72 \\
-0.59)\end{array}$ & 0.84 & 0.55 & & $\begin{array}{l}1.73(-0.59- \\
1.70)\end{array}$ \\
\hline No & Referent & Referent & Referent & Referent & Referent & Referent & Referent & Referent & Referent & Referent & Referent \\
\hline $\begin{array}{l}\text { Manager } \\
\text { experience } \\
<10\end{array}$ & Referent & Referent & Referent & Referent & Referent & Referent & Referent & Referent & Referent & Referent & Referent \\
\hline$<20$ & -0.15 & 0.34 & $\begin{array}{l}0.85(-1.06 \\
-0.76)\end{array}$ & 0.74 & 0.27 & 1.11 & $\begin{array}{l}1.31(-1.38 \\
-1.93)\end{array}$ & 0.74 & -12.99 & 0.00 & $\begin{array}{l}2.27(-3043.04 \\
-\quad 3017.05)\end{array}$ \\
\hline$<30$ & -0.62 & 0.23 & $0 .-149$ & 0.16 & -0.51 & 0.50 & & 0.54 & -15.49 & 0.00 & \\
\hline $\begin{array}{l}<30 \\
>30\end{array}$ & -0.17 & 0.55 & $\begin{array}{l}0.53(-1.49 \\
-0.25)\end{array}$ & 0.22 & -0.28 & 0.87 & $\begin{array}{l}0.59(-2.17 \\
-1.15)\end{array}$ & 0.80 & Referent & Referent & $\begin{array}{l}1.8 /(-3045.54 \\
-\quad 3014.55)\end{array}$ \\
\hline & & & $\begin{array}{l}0.84(-1.47 \\
-\quad 1.12)\end{array}$ & & & & $\begin{array}{l}0.75(-2.55 \\
-1.99)\end{array}$ & & & & Referent \\
\hline Degree & & & & & & & & & & & \\
\hline Primarily & Referent & Referent & Referent & Referent & Referent & Referent & Referent & Referent & Referent & Referent & Referent \\
\hline Elementary & -0.16 & 0.22 & $0.85(-0.68$ & 0.54 & -0.71 & 0.19 & $0.48(-1.51$ & 0.07 & -2.31 & 0.09 & $0.09(-4.27-$ \\
\hline Secondary & 0.78 & 0.62 & $\begin{array}{l}2.19(0.22 \text { - } \\
1.34)\end{array}$ & $0.00^{*}$ & 0.91 & 1.03 & $\begin{array}{l}2.48(0.09 \\
-\quad 1.72)\end{array}$ & $0.02 *$ & 1.79 & 5.15 & $\begin{array}{l}5.99(0.10- \\
3.47)\end{array}$ \\
\hline School size & & & & & & & & & & & \\
\hline$<=150$ & Referent & Referent & Referent & Referent & Referent & Referent & Referent & Referent & Referent & Referent & Referent \\
\hline $151-300$ & Referent & Referent & Referent & Referent & Referent & Referent & Referent & Referent & Referent & Referent & Referent \\
\hline$>300$ & -0.20 & 0.23 & $\begin{array}{l}0.19(-0.68 \\
-0.27)\end{array}$ & 0.40 & -0.05 & 0.35 & $\begin{array}{l}0.94(-0.77 \\
-0.67)\end{array}$ & 0.88 & -0.96 & 0.24 & $\begin{array}{l}0.38(-2.20 \\
0.27)\end{array}$ \\
\hline Life with & & & & & & & & & & & \\
\hline Double & Referent & Referent & Referent & Referent & Referent & Referent & Referent & Referent & Referent & Referent & Referent \\
\hline Sinqle & 0.11 & 0.42 & $\begin{array}{l}1.11(-0.63 \\
-0.86)\end{array}$ & 0.76 & 0.53 & 0.81 & $\begin{array}{l}1.70(-0.40 \\
-1.47)\end{array}$ & 0.26 & 0.77 & 1.45 & $\begin{array}{l}2.16(-0.54- \\
2.08)\end{array}$ \\
\hline $\begin{array}{l}\text { parents } \\
\text { Other }\end{array}$ & 0.77 & 1.00 & $\begin{array}{l}2.17(-0.13 \\
-1.68)\end{array}$ & 0.09 & 0.68 & 1.36 & $\begin{array}{l}1.98(-0.66 \\
-2.03)\end{array}$ & 0.31 & 2.37 & 8.60 & $\begin{array}{l}10.70(0.79- \\
3.94)\end{array}$ \\
\hline $\begin{array}{l}\text { Social and } \\
\text { economic } \\
\text { statue }\end{array}$ & Referent & Referent & Referent & Referent & Referent & Referent & Referent & Referent & Referent & Referent & Referent \\
\hline lowest & -0.60 & 0.34 & $\begin{array}{l}0.54(-1.82 \\
-0.62)\end{array}$ & 0.33 & -1.87 & 0.15 & $\begin{array}{l}0.15(-3.79 \\
-0.04)\end{array}$ & $0.05^{*}$ & Referent & Referent & Referent \\
\hline low & 0.05 & 0.60 & $106(-105$ & 0.91 & -0.83 & 0.32 & $0.43(-232$ & 0.27 & -0.14 & 1.10 & $0.86(-2.65-$ \\
\hline moderate & 0.09 & 0.63 & $-1.17)$ & 0.86 & -0.56 & 0.42 & $-0.65)$ & 0.45 & 0.35 & 1.82 & $143(-2) 13-$ \\
\hline $\begin{array}{l}\text { high } \\
\text { very high }\end{array}$ & 0.30 & 0.81 & $\begin{array}{l}1.10(-1.02 \\
-1.21)\end{array}$ & 0.57 & -0.13 & 0.66 & $\begin{array}{l}0.56(-2.03 \\
-0.91)\end{array}$ & 0.85 & 1.00 & 3.51 & $\begin{array}{l}2.85) \\
2.73(-1.51- \\
3.52)\end{array}$ \\
\hline
\end{tabular}




\begin{tabular}{|c|c|c|c|}
\hline & & & \\
\hline LR chi2 & 48.12 & 62.59 & 46.12 \\
\hline AIC & 785.80 & 430.29 & 191.90 \\
\hline BIC & 870.65 & 515.18 & 264.37 \\
\hline
\end{tabular}

Coefficient 0.05

Table 5:The factors affecting on buller using multi logistic regression model 


\begin{tabular}{|c|c|c|c|c|c|c|c|c|}
\hline \multirow[t]{2}{*}{ Variable } & \multicolumn{4}{|c|}{ Emotional buller } & \multicolumn{4}{|c|}{ Other buller } \\
\hline & $\beta$ & $\begin{array}{l}\text { Standard } \\
\text { error }\end{array}$ & OR; $95 \% \mathrm{CL}$ & $P$ value & $\beta$ & $\begin{array}{l}\text { Standard } \\
\text { error }\end{array}$ & OR; $95 \% \mathrm{CL}$ & $P$ value \\
\hline \multicolumn{9}{|c|}{ School ownership } \\
\hline Public & -0.31 & 0.61 & $0.72(-1.96-1.32)$ & 0.70 & -0.07 & 0.82 & $\begin{array}{l}0.92(-1.81- \\
1.66)\end{array}$ & 0.93 \\
\hline Non-public & Referent & Referent & Referent & Referent & Referent & Referent & Referent & Referent \\
\hline \multicolumn{9}{|l|}{ Sex } \\
\hline Female & Referent & Referent & Referent & Referent & Referent & Referent & Referent & Referent \\
\hline Male & 1.22 & 1.49 & $3.40(0.36-\quad 2.08)$ & $0.00 *$ & 1.94 & 3.91 & $6.96(0.83-3.04)$ & $0.00 *$ \\
\hline \multicolumn{9}{|l|}{ Promotion } \\
\hline Yes & 0.16 & 0.57 & $1.18(-0.77-\quad 1.11)$ & 0.72 & 0.45 & 0.78 & $\begin{array}{l}1.58(-0.51- \\
1.43)\end{array}$ & \\
\hline No & Referent & Referent & Referent & Referent & Referent & Referent & Referent & Referent \\
\hline \multicolumn{9}{|l|}{ Adviser } \\
\hline Yes & -0.09 & 0.37 & $0.91(-0.90-\quad 0.71)$ & 0.82 & 0.51 & 0.74 & $\begin{array}{l}1.67(-0.35- \\
1.38)\end{array}$ & \\
\hline No & Referent & Referent & Referent & Referent & Referent & Referent & Referent & Referent \\
\hline \multicolumn{9}{|c|}{ Manager experience } \\
\hline$<10$ & Referent & Referent & Referent & Referent & Referent & Referent & Referent & Referent \\
\hline$<20$ & -0.81 & 0.33 & $0.44(-2.29-\quad 0.66)$ & 0.28 & 0.69 & 2.25 & $\begin{array}{l}2.00(-1.50- \\
2.90)\end{array}$ & 0.53 \\
\hline$<30$ & -1.14 & 0.22 & $0.31(-2.51-\quad 0.23)$ & 0.10 & -0.33 & 0.81 & \multirow{2}{*}{$\begin{array}{l}0.71(-2.59 \text { - } \\
1.91)\end{array}$} & 0.76 \\
\hline \multirow[t]{2}{*}{$>30$} & \multirow[t]{2}{*}{-0.86} & \multirow[t]{2}{*}{0.48} & \multirow{2}{*}{$\begin{array}{l}0.42(-3.13 \\
1.41)\end{array}$} & \multirow[t]{2}{*}{0.45} & \multirow[t]{2}{*}{-0.59} & \multirow[t]{2}{*}{0.86} & & 0.70 \\
\hline & & & & & & & $\begin{array}{l}0.55(-3.64- \\
2.46)\end{array}$ & \\
\hline \multicolumn{9}{|l|}{ Degree } \\
\hline Primarily & Referent & Referent & Referent & Referent & Referent & Referent & Referent & Referent \\
\hline Elementary & -0.89 & 0.20 & $0.41(-1.88-0.10)$ & 0.08 & -1.25 & 0.14 & $0.28(-2.27--0.22)$ & $0.01 *$ \\
\hline Secondary & 0.70 & 0.97 & $\begin{array}{l}2.02(-0.23 \quad- \\
1.64)\end{array}$ & 0.14 & 0.55 & 0.91 & $\begin{array}{l}1.74(-0.45- \\
1.57)\end{array}$ & 0.28 \\
\hline \multicolumn{9}{|l|}{ School size } \\
\hline$<=150$ & Referent & Referent & Referent & Referent & Referent & Referent & Referent & Referent \\
\hline $151-300$ & Referent & Referent & Referent & Referent & Referent & Referent & Referent & Referent \\
\hline$>300$ & 0.46 & 0.69 & $\begin{array}{l}1.58(-0.39 \\
1.31)\end{array}$ & 0.29 & -0.25 & 0.33 & $\begin{array}{l}0.77(-1.11- \\
0.59)\end{array}$ & 0.55 \\
\hline Life with & & & & & & & & \\
\hline Double parents & Referent & Referent & Referent & Referent & Referent & Referent & Referent & Referent \\
\hline Single parents & -0.33 & 0.20 & $0.71(-1.80-1.12)$ & 0.65 & -1.04 & 0.36 & $0.35(-3.07-$ & 0.31 \\
\hline Other & 1.17 & 0.97 & $\begin{array}{l}3.22(-0.15- \\
2.49)\end{array}$ & 0.08 & 1.36 & 2.73 & $\begin{array}{l}3.92(-0.00- \\
2.73)\end{array}$ & $0.05^{\star}$ \\
\hline $\begin{array}{l}\text { Social and econ } \\
\text { statue }\end{array}$ & Referent & Referent & Referent & Referent & Referent & Referent & Referent & Referent \\
\hline low & 0.53 & 1.98 & $1.70(-1.76-\quad 2.82)$ & 0.65 & -0.10 & 1.12 & $\begin{array}{l}0.89(-2.56- \\
235)\end{array}$ & 0.93 \\
\hline moderate & 0.37 & 1.68 & $1.46(-1.88-2.64)$ & 0.74 & 0.64 & 2.26 & $190(-168-$ & 0.58 \\
\hline & 0.44 & 1.80 & $1.56(-1.82-2.71)$ & 0.70 & 0.84 & 2.78 & $2.97)$ & 0.47 \\
\hline very high & 0.98 & 3.11 & $\begin{array}{l}2.67(-1.30- \\
3.26)\end{array}$ & 0.39 & 0.82 & 2.79 & $\begin{array}{l}2.33(-1.48- \\
3.18)\end{array}$ & 0.49 \\
\hline & & & & & & & $\begin{array}{l}2.28(-1.56- \\
3.22)\end{array}$ & \\
\hline
\end{tabular}




\begin{tabular}{|lll|} 
Wald chi2 & 26.51 & 28.07 \\
\hline ICC & 6.24 & 3.22 \\
\hline AIC & 354.45 & 319.92 \\
\hline BIC & 439.39 & 404.83 \\
\hline
\end{tabular}

Coefficient 0.05

Page 18/18 